\title{
Meat and bone meal as a novel biostimulation agent in hydrocarbon contaminated soils
}

\author{
Liu, Xinxin
}

2019-06

Liu , X, Selonen , V , Steffen , K, Surakka , M , Rantalainen, A-L, Romantschuk , M \& Sinkkonen, A 2019 , ' Meat and bone meal as a novel biostimulation agent in hydrocarbon contaminated soils ' , Chemosphere , vol. 225 , pp. 574-578 . https://doi.org/10.1016/j.chemosphere.2019.03.053

http://hdl.handle.net/10138/327776

https://doi.org/10.1016/j.chemosphere.2019.03.053

cc_by_nc_nd

acceptedVersion

Downloaded from Helda, University of Helsinki institutional repository.

This is an electronic reprint of the original article.

This reprint may differ from the original in pagination and typographic detail.

Please cite the original version. 


\section{Accepted Manuscript}

Meat and bone meal as a novel biostimulation agent in hydrocarbon contaminated soils

Xinxin Liu, Ville Selonen, Kari Steffen, Mea Surakka, Anna-Lea Rantalainen, Martin Romantschuk, Aki Sinkkonen

PII: S0045-6535(19)30489-8

DOI: 10.1016/j.chemosphere.2019.03.053

Reference: CHEM 23367

To appear in: Chemosphere

Received Date: 18 June 2018

Accepted Date: 10 March 2019

Please cite this article as: Xinxin Liu, Ville Selonen, Kari Steffen, Mea Surakka, Anna-Lea Rantalainen, Martin Romantschuk, Aki Sinkkonen, Meat and bone meal as a novel biostimulation agent in hydrocarbon contaminated soils, Chemosphere (2019), doi: 10.1016/j.chemosphere. 2019.03.053

This is a PDF file of an unedited manuscript that has been accepted for publication. As a service to our customers we are providing this early version of the manuscript. The manuscript will undergo copyediting, typesetting, and review of the resulting proof before it is published in its final form. Please note that during the production process errors may be discovered which could affect the content, and all legal disclaimers that apply to the journal pertain. 
1 Meat and bone meal as a novel biostimulation agent in hydrocarbon contaminated soils

2 Xinxin Liu*, Ville Selonen, Kari Steffen, Mea Surakka, Anna-Lea Rantalainen, Martin

3 Romantschuk, Aki Sinkkonen*

4

5 Faculty of Biological and Environmental Sciences, University of Helsinki, Niemenkatu 73, 15140,

6 Lahti, Finland

7

8 *Corresponding authors:

$9 \quad$ Xinxin Liu

10 xin.lin@helsinki.fi

$11+358445876678$

12 Niemenkatu 73, 15140, Lahti, Finland

13

14 Aki Sinkkonen

15 aki.Sinkkonen $@$,helinki.fi

$16+35850332110$

17 Niemenkatu 73, 15140, Lahti, Finland

18

19

20

21 


\section{Abstract}

23

Soil contamination with diesel oil is frequent and methods to improve remediation of diesel oil contaminated soils are urgently needed. The aim of the current study was to assess the potential of meat and bone meal (MBM) as a biostimulation agent to enhance diesel oil degradation in contaminated soils collected from southern Finland. MBM (2\% w/w) increased oil degradation in soils when compared to natural attenuation. The increase was comparable to soils treated with a traditional fertilizer (urea). Soil pH increased rapidly in urea treated soil but remained at the level of natural attenuation in MBM treated soil, suggesting that in large-scale experiments MBM treated soils avoid the usual negative impact of urea on soil $\mathrm{pH}$ and ultimately microbial degradation. These results indicate that MBM addition enhances diesel oil degradation, and that MBM speeds up ex situ bioremediation of oil contaminated soils.

Key words: crude oil; diesel oil; meat and bone meal; remediation; biostimulation 


\section{Introduction}

Hydrocarbon contaminated land sites pose risks both to the environment and to human health (Robertson and Hansen, 2015; Parajuli et al., 2017; Roslund et al., 2018). Diesel oil is composed of different mixtures of alkanes and aromatic compounds that are frequently reported to pollute terrestrial environments as a result of accidental spillage or leakage by storage tanks or pipelines. The capacity of natural microbial communities to metabolize hydrocarbons has been recognized widely (Kauppi et al., 2012; Sinkkonen et al., 2013; Varjani, 2017). However, natural attenuation of diesel oil is often slow and inefficient. Diesel oil bioremediation in soil can be promoted by stimulation of the indigenous microorganisms, e.g. by introducing nutrients and oxygen into the soil (Bento et al., 2005; Kauppi et al., 2011), and alternative solutions, such as electro-osmotic dewatering, have been searched for (Simpanen et al., 2017). A main problem with currently existing biostimulation agents and technologies is their high price tag.

In case of ex situ or in situ remediation attempts, biological activity and the biodegradation rate are often limited by nutrient and oxygen supplies (Akbari and Ghoshal, 2014; Wang et al., 2016; Mikkonen et al., 2018). Urea is one of the most cost-effective biostimulation agents that can be applied to contaminated soil to increase nutrient supply, particularly as a nitrogen source (Brook et al., 2001). However, the use of urea as an additive in soil remediation causes $\mathrm{pH}$ to detrimentally rise above eight, fast nitrification and a drop in bacterial viability (Peltola et al., 2006; Geisseler and Scow, 2014). Additionally, urea is solubilized rather rapidly, which results in leaching of nutrients. The leaching shortens the duration of the remediation effect and may cause environmental issues (Peltola et al., 2006). Hence, cost-effective alternatives that are not used as crop fertilizers are needed.

Meat and bone meal (MBM), a by-product of the rendering industry, contains a large number of nutritive elements such as $\mathrm{C}(\approx 30 \%) \mathrm{N}(\approx 8 \%), \mathrm{P}(\approx 5 \%), \mathrm{Ca}(\approx 10 \%)$ mainly in slowly-soluble organic forms. The $\mathrm{N}: \mathrm{P}$ ratio ranges from 0.5 to 2 and $\mathrm{C}: \mathrm{N}$ ratio from 3 to 4 , and $\mathrm{MBM}$ also 
contains $\mathrm{K}, \mathrm{Ca}, \mathrm{Mg}$ and $\mathrm{O}$ (Jeng et al., 2004). These features make MBM a stable source of nutrients, indeed MBM has been associated with enhanced activity of soil microbes (Mondini et al., 2008), and it is currently used as crop fertilizer (Kivelä et al. 2015). Based on this, we hypothesized that adding MBM to contaminated soil may enhance oil degradation. Surprisingly, soil remediation potential of MBM has not earlier been investigated, but MBM-based 3\% (w/w) biochar was found to increase the petroleum hydrocarbon degradation rate constants in frozen soils when compared to the urea amended soils (Karppinen et al., 2017). The present study aims to introduce MBM as a novel biostimulation agent in oil contaminated soils. We hypothesize that i) the diesel oil biodegradation can be enhanced by addition of MBM, and ii) MBM addition does not increase soil $\mathrm{pH}$ above eight.

\section{Materials and Methods}

The diesel oil (Neste Green -diesel, EN 590) was purchased from Neste gasoline station, Lahti. Finland. Rendered and powdered meat bone meal [MBM, class 2 in Commission Regulation (EU) 142/2011] was provided by Honkajoki Oy, Honkajoki, Finland.

Ex situ remediation of diesel oil contaminated soil.

The soil was sandy mineral soil that originated from an old petrol station. Soil $\mathrm{pH}$ was 6.7, water holding capacity was $21.5 \%$, and organic carbon content was $0.6 \%(\mathrm{w} / \mathrm{w})$. The oil contaminated soil was excavated and a part of it transported to a laboratory and mixed thoroughly. Remediation by natural attenuation and remediation by MBM treatment were studied simultaneously in a laboratory and in an ex situ site as an off-site treatment. In the ex situ site, the contaminated soil was divided into two separate heaps. One of the heaps was left for remediation by natural attenuation and the other was treated with $2 \% \mathrm{w} / \mathrm{w}$ MBM. The volume of each heap was approximately $4.5 \mathrm{~m}^{3}$, and the mass of each heap was approximately $7000 \mathrm{~kg}$. The MBM was 
mixed into the soil by an excavator with a screening bucket. Natural attenuation heap was mixed in the same way without using MBM.

The moisture content of the heaps was visually estimated by experienced personnel who neither knew about the treatments nor were aware of the purpose of the study. In visual estimation, the moisture level is evaluated daily all over the heaps. The visual estimation, as a routine operational procedure, is usually conducted in real applications and it typically leads to successful bioremediation in large-scale remediation attempts. If the soil looks almost too dry for microbial activity, water was added during the weekly admixture of the heap. The heaps were covered with tarpaulin, which reduced evaporation and kept moisture content adequate for most of the time. The first sampling was done at the start of the experiment (day 0) and the second sampling was performed on day 28 . The third sampling was performed 99 days from the day 0 . The experiment lasted from July $29^{\text {th }}, 2016$ to early November in Lahti, Finland. Monthly means in air temperature were $14.8{ }^{0} \mathrm{C}$ (August), $11.1^{\circ} \mathrm{C}$ (September), $3.7^{\circ} \mathrm{C}$ (October), and $-1.4^{\circ} \mathrm{C}$ (November) (Finnish Meteorological Institute).

Lab remediation of diesel oil contaminated soil

In the laboratory, an experiment mimicking the field study was conducted. Instead of heaps, replicates of contaminated soil were placed in $1 \mathrm{~L}$ polyethene cylinders with lids. Each cylinder was filled with 1000 grams of contaminated soil and closed with tight lids. Half of the cylinders were anaerobic without an aeration, whereas the rest of the cylinders were aerobic equipped with air pumps. Air was pumped in through a $\varnothing 10 \mathrm{~mm}$ hole of each cylinder. Air flow was $1.75 \mathrm{~L} \mathrm{~min}^{-1}$ (Sera air 275 R plus, Sera, Germany). There were three MBM (2\% w/w) replicates and three natural attenuation replicates. The admixture was done by rolling over and turning the cylinder upside down several times. The moisture content of the samples was monitored by weighing the 
pots and calibrating them to the original weight at two weeks intervals. The temperature in the laboratory was adjusted to a room temperature of $21^{\circ} \mathrm{C}$.

Samplings were done at the start of the experiments (day 0) and at time points day 28, 79, and 99. At each sampling, each cylinder was sampled. For each sample, three subsamples were taken from three random spots and immediately combined and mixed thoroughly. The same sampling method was repeated in the ex situ field experiment. Samples were collected in sealable plastic bags, transferred to the laboratory and stored immediately in a freezer $\left(-21^{\circ} \mathrm{C}\right)$. All samples were analysed as triplicates, i.e., three samples per sampling point per heap or cylinder were analysed.

\section{Effect of meat and bone meal on $\mathrm{pH}$-values of diesel-oil contaminated soil}

We first wanted to find out whether MBM is comparable to natural attenuation in terms of slow and relatively small changes in soil $\mathrm{pH} . \mathrm{pH}$ in diesel oil contaminated sand (particle size $\max 4 \mathrm{~mm}$ ) was followed once a week for 28 days (see Roslund et al. 2018 for a detailed description of the sand). The sand contaminated four years earlier with Neste Green diesel as described earlier (Simpanen et al., 2016) contained oil at the concentration $1500 \mathrm{mg} \mathrm{kg}^{-1}$ at the onset of the experiment described here. The sand was treated with a biostimulation agent, either with $0.5 \% \mathrm{w} / \mathrm{w}$ MBM, $4 \% \mathrm{w} / \mathrm{w}$ MBM or with urea, or remediated by natural attenuation. Each treatment included three replicates. The amount of urea-N was calculated to correspond to a C:N ratio of 100:1. The total amount of carbon in the sand, calculated from the organic matter content, was $0.9 \% \mathrm{w} / \mathrm{w}$. All biostimulation agents were added in the beginning of the study, after which each replicate was placed in $5 \mathrm{dL}$ glass containers (diameter $85 \mathrm{~mm}$, height $125 \mathrm{~mm}$ ), and the containers were covered with petri dishes. A Petri dish is not a hermetic cover; therefore, passive aeration existed underneath the Petri dish. The amount of sand per container was $200 \mathrm{~g}$. Throughout the experiment, soil moisture was kept at $60 \%$ of the water holding capacity in all samples, and the glasses were located 
133

134

135

136

137

138

139

140

141

142

in an incubator at $27.5^{\circ} \mathrm{C}$. A total of five samplings was conducted. The sampling was done weekly. At each sampling, approximately $3.33 \mathrm{~g}$ of sand was sampled from each container. Three $3.33 \mathrm{~g}$ subsamples, all exposed to the same conditions, were mixed together and the $\mathrm{pH}$-value of the combined sample was measured. Due to the small amount of sand in each container, only $\mathrm{pH}-$ sampling was included and oil degradation sampling excluded from this experiment.

Physical and chemical analyses

Soil dry weight was determined from the weight loss after heat treatment $\left(20 \mathrm{~h}\right.$ at $\left.105^{\circ} \mathrm{C}\right)$. Soil $\mathrm{pH}$ was determined with a glass electrode. Soil $\mathrm{pH}$ measurements were done by weighing the $10 \mathrm{~g}$ soil sample in a sample flask. $75 \mathrm{~mL}$ of $0.01 \mathrm{M} \mathrm{CaCl}_{2}$ solution was added to the containers, then shaken (250 rpm) for one hour. $\mathrm{pH}$ was measured two hours after stopping shaking. The measurement was done with an inoLab pH 720 device. The oil compounds were analyzed from the samples according to slightly modified ISO16703 (2015) standard. In brief, two grams (wet weight) of soil was extracted with a mixture of acetone $(4 \mathrm{~mL})$ and hexane $(2 \mathrm{~mL}$, containing integration standards decane and tetracontane). Extraction took place in $10 \mathrm{~mL}$ test tube by shaking $1 \mathrm{~h}$ at speed $200 \mathrm{rpm}$. The acetone was removed by washing the sample twice with $2 \mathrm{~mL}$ of water. Diesel concentration in the sample was quantified by using dilution series of diesel as external standards. Final analysis was done with a gas chromatograph equipped with a Zebron ZB-5HT Inferno capillary column (length $15 \mathrm{~m}$, inner diameter $320 \mu \mathrm{m}$ and phase thickness $0.1 . \mu \mathrm{m}$ ) and flame ionization detector (GC-FID, Agilent 6890N). GC oven temperature programme was started from $50{ }^{\circ} \mathrm{C}$ (hold $2 \mathrm{~min}$ ), increased at rate $20^{\circ} \mathrm{C} / \mathrm{min}$. to $320^{\circ} \mathrm{C}$ and hold there for $10 \mathrm{~min}$.

\section{Statistical analyses}


Differences in diesel oil removal percentage in different ex situ treatments (MBM, urea, natural attenuation) were evaluated using t-tests. False Detection Rate (FDR) corrections were used in the ttest results. The anaerobic and aerobic treatment were compared after 99 day process, differences in diesel oil removal percentage in different lab treatments (MBM, urea, and natural attenuation) were evaluated using analysis of variance (ANOVA).

\section{Results}

Ex situ remediation of diesel oil contaminated soil

At the start (day 0), the concentration of oil hydrocarbons in the heaps was $737 \pm 269 \mathrm{mg} / \mathrm{kg}$ (mean $\pm \mathrm{SD}$; fractions $\mathrm{C} 10-\mathrm{C} 21)$. The natural attenuation reduced the concentration of oil compounds with $20 \%$, and the MBM treatment reduced the concentration by $50 \%$ in 28 days $(\mathrm{t}=$ 7.25, $\mathrm{n}=3, \mathrm{p}=0.0416)$. After three months (99 days), the reduction of diesel oil was $30 \%$ in the natural attenuation treatment and more than $50 \%$ in the MBM treatment $(\mathrm{t}=11.21, \mathrm{n}=3, \mathrm{p}=$ 0.0195). Importantly, in the MBM treatment diesel oil concentration varied between 199-469 and 343-357 $\mathrm{mg} \mathrm{kg}^{-1}$ after 28 and 99 days, respectively, while diesel oil concentrations in the control treatment varied between $437-967$ and $438-567 \mathrm{mg} \mathrm{kg}^{-1}$, respectively. This means that both the mean and the maximum values were lower in MBM treated soil compared to natural attenuation treatment in ex situ conditions.

Lab remediation of diesel oil contaminated soil

To investigate the efficacy of MBM in diesel bioremediation, the effect of MBM and urea was compared with a natural attenuation treatment in laboratory conditions. In general, oil degradation 
was fast during the first 28 days in MBM and urea treatments ( $>77 \%$ removal). Thereafter, the residual concentrations decreased slowly (Fig. 1). Diesel oil hydrocarbon concentrations were always higher in the natural attenuation treatment, compared to the other two treatments $(\mathrm{t}=67.22$, $\mathrm{df}=2, \mathrm{p}=0.0016)$. At the end of the experiment, the residual concentrations were more than twice (ca. $1700 \mathrm{mg} \mathrm{kg}^{-1}$ ) as high in the natural attenuation treatment as in the MBM and urea treatments $\left(<850 \mathrm{mg} \mathrm{kg}^{-1}\right)$.

In the anaerobic treatment, the concentration of oil hydrocarbons was $8758 \pm 623 \mathrm{mg} / \mathrm{kg}$ (mean $\pm \mathrm{SD}$ ) at 0 day. After 99 days of process, the concentrations of oil in control soils dropped to $3912 \pm 2058$ $\mathrm{mg} / \mathrm{kg}$. In MBM and urea treatments, the residual content of oil were $4693 \pm 411 \mathrm{mg} / \mathrm{kg}$ and $4757 \pm 129 \mathrm{mg} / \mathrm{kg}$, respectively. In MBM, urea treated and control soils, the degradation activities under anaerobic condition were significantly lower than in aeration conditions $(M B M, t=5.17, n=$ $3, \mathrm{p}=0.0067$; urea, $\mathrm{t}=18.68 .14, \mathrm{n}=3, \mathrm{p}<0.001 ;$ control, $\mathrm{t}=3.32, \mathrm{n}=3, \mathrm{p}=0.0293)$. The aeration increased the degradation significantly, indicating oxygen is essential in diesel oil degradation. MBM and urea did not show significant effect on diesel oil degradation in anaerobic treatments (F $=0.362, \mathrm{df}=2, \mathrm{p}=0.711)$, while the difference of oil degradation in MBM and urea treated soil under aerobic conditions was significant $(\mathrm{F}=108.418, \mathrm{df}=2, \mathrm{p}<0.001)$. 
195

196

197

198

199

200

201

202

203

204

205

206

207

208

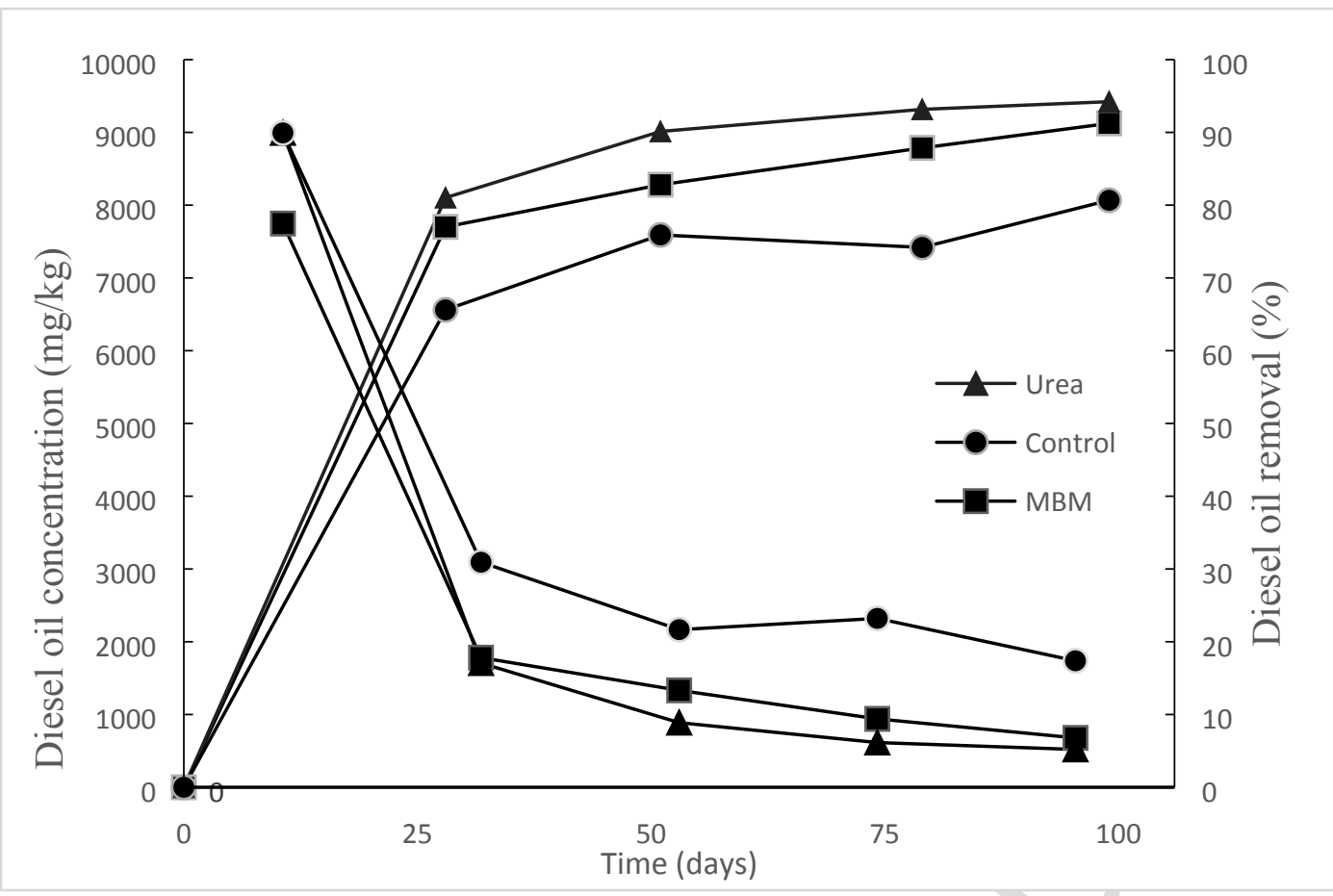

Figure 1. Diesel oil removal and concentrations in the aerobic treatment. Urea denotes oil contaminated soil treated with urea, MBM denotes oil contaminated soil treated with meat and bone meal and Control denotes oil contaminated soil with natural attenuation. The sampling points are days $0,28,51,79$, and 99

$\mathrm{pH}$ in diesel oil contaminated soils

In the first two weeks of the study, urea treatment increased the $\mathrm{pH}$ intensively. The initially measured soil $\mathrm{pH}$ of urea treated soil $(\mathrm{pH} 7.08)$ increased to 8.69 during the first 7 days of the study and then decreased to 7.94. The control treatment and MBM treated soils reached the highest $\mathrm{pH}$ on day 14 (pH ranged 7.62 to 8.01 ). On day 28, the MBM treatment had not increased $\mathrm{pH}-$ level above eight in diesel oil contaminated soil (Fig.2). During the 28 days of study, the $\mathrm{pH}$ of MBM treated soils remained more stable in the neutral range $(\mathrm{pH} 7.0$ to 7.5), which is favourable for biodegradation. These results indicated that $\mathrm{MBM}$ avoids rapid $\mathrm{pH}$ fluctuation of urea as a bioremediation agent. 


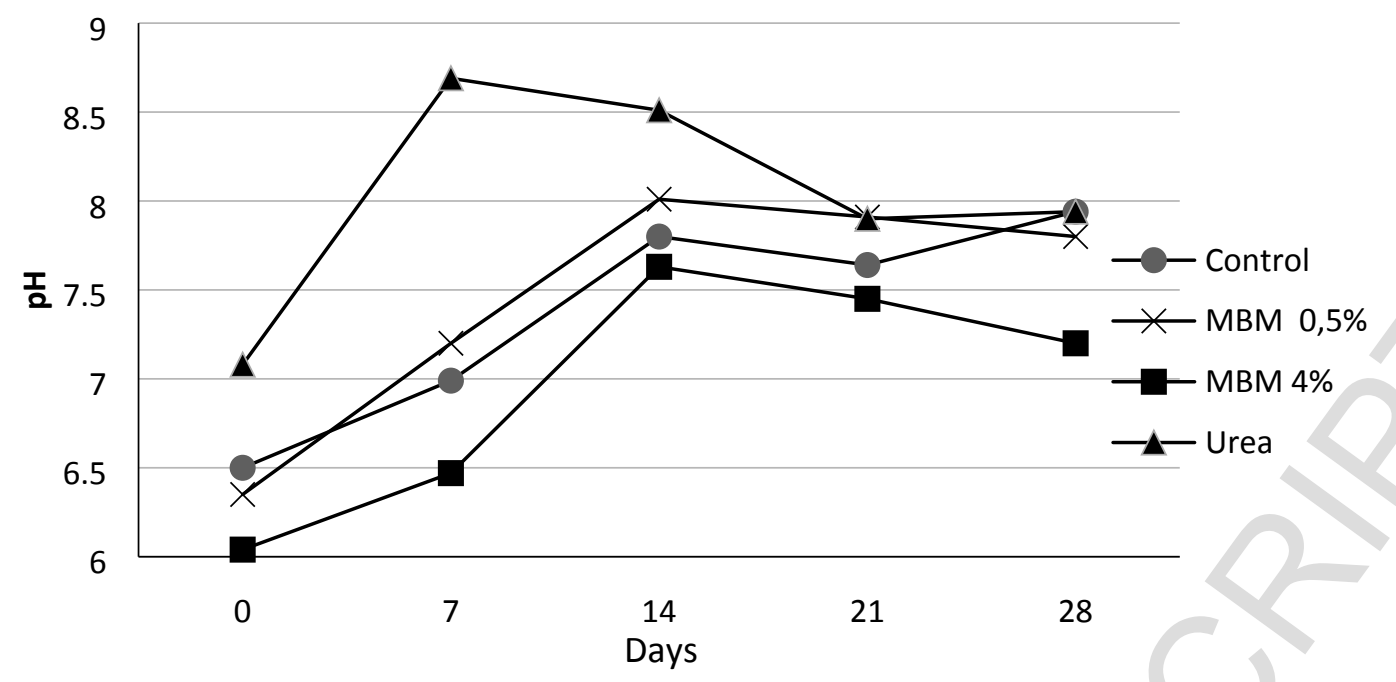

211 Figure 2. $\mathrm{pH}$ as a function of time in diesel oil contaminated sand. MBM $0.5 \%=$ contaminated sand treated with meat bone meal $(0.5 \% \mathrm{w} / \mathrm{w})$. MBM $4 \%=$ contaminated sand treated with meat bone meal $(4 \% \mathrm{w} / \mathrm{w})$. Urea $=$ contaminated sand treated with urea $(2 \% \mathrm{w} / \mathrm{w}$, day 0$)$. Control $=$ contaminated sand.

\section{Discussion}

We performed three experiments in which the suitability of meat and bone meal was evaluated as a novel biostimulation agent. In actively aerated mesocosms amended with MBM $(2 \% \mathrm{w} / \mathrm{w})$, a $91.2 \%$ reduction in diesel oil content was reached in 99 days, of which $77.0 \%$ was reduced within the first 28 days. Similarly, the ex situ pilot scale experiment resulted in significantly faster remediation in the MBM than the natural attenuation treatment. The efficacy of MBM and urea treatments was equal in the mesocosm experiment. As MBM contains more slowly soluble than readily available N, $\mathrm{P}$ and $\mathrm{K}$, and as MBM is of animal origin and suitable for stimulation of microbial activity (Mondini et al., 2008), it is plausible to assume that MBM is comparable to or more efficient than urea and other traditional N and NPK fertilizers as a biostimulation agent in contaminated soils. rapid release of ammonia, which increases soil alkalinity and causes inhibition of microbial activity 
228 (Valentine and Bradfield, 1954; Zhou and Crawford, 1995; Peltola et al., 2006). Further, the 229 resulting conditions promote ammonification and release of ammonia (Kurola et al., 2005) 230 Although some studies have found MBM to increase soil $\mathrm{pH}$, in those studies the MBM used was manufactured using different and an outdated rendering technique(Lazarovits et al., 1999).

The favourable $\mathrm{pH}$ for diesel fuel biodegradation and bacterial activities in soil has been reported as neutral or slightly alkaline (Wongsa et al., 2004). In the current study, active aeration probably prevented or at least reduced a change in $\mathrm{pH}$ and thus its negative effects on oil degradation in the urea treatment, but active aeration may not be a cost-effective option in large scale commercial remediation. As MBM contains both fast and slowly soluble nutrients, we monitored the possible $\mathrm{pH}$ effects of MBM in a separate, non-aerated experiment, and found out that $\mathrm{pH}$ stayed neutral or slightly alkaline throughout the experimental period, as an opposite to the urea treatment. The $\mathrm{pH}-$ test was done with a very high and a very low MBM percentage. In the oil degradation tests, MBM concentration was intermediate. As the difference in $\mathrm{pH}$ between the low and the high percentage was negligible, it is plausible that $\mathrm{pH}$ stays at or below 8 also in the degradation tests. The finding is important as it suggests that microbial activity does not cease soon after MBM addition as it often does in case of urea addition (Kauppi et al., 2011).

The fact that diesel oil degradation is enhanced by MBM amendment supports our first hypothesis that MBM is a potential biostimulation agent for oil bioremediation. This is in accordance with earlier findings that the addition of organic amendments can increase the degradation rate of target contaminants (Sinkkonen et al., 2013). The reason for the efficacy of some organic amendments is that they provide lacking nutrients coupled with organic compounds, which stimulates microbial growth., consequently enhancing the microbial degradation.. 
251 We did not determine volatilization and adsorption to organic substances, but it is likely that neither 252 of them differed between natural attenuation and biostimulation treatments. The reason is that even 253 though MBM contains a diverse mixture of organic carbon sources that could enhance adsorption 254 (Endo et al., 2009), the disappearance of diesel oil hydrocarbons was at the same level in MBM and 255 urea treated pots in our study. In an earlier study, the volatilization of $n$-alkanes decreased when the 256 amount of organic amendment to the soil increased (Namkoong et al., 2002) suggesting that also 257 MBM would rather decrease than increase volatilization compared to the natural attenuation 258 treatment.

\section{Conclusions.}

The purpose of this study was to evaluate whether meat and bone meal is suitable for oil remediation. We performed experiments with different contaminated soils in the lab and at a pilot scale ex situ. The results show that MBM is suitable to be used as a biostimulation agent in the remediation of oil polluted soils. The MBM assisted biodegradation of contaminated environments can become a sustainable and economically feasible strategy to recycle MBM.

\section{Acknowledgements}

The study was funded by Tekes - Finnish Funding Acency for Technology and Innovation (grant 40333/14) and by the University of Helsinki. Hannu Silvennoinen at Nordic Envicon Oy provided ex situ site and contaminated soils.

\section{Reference}

Akbari, A., Ghoshal, S., 2014. Pilot-scale bioremediation of a petroleum hydrocarbon-contaminated clayey 
Bento, F.M., Camargo, F.A., Okeke, B.C., Frankenberger, W.T., 2005. Comparative bioremediation of soils contaminated with diesel oil by natural attenuation, biostimulation and bioaugmentation. Bioresour. Technol. 96, 1049-1055.

Brook, T.R., Stiver, W.H., Zytner, R.G., 2001. Biodegradation of diesel fuel in soil under various nitrogen addition regimes. Soil Sediment Contam. 10, 539-553.

Endo, S., Grathwohl, P., Haderlein, S.B., Schmidt, T.C., 2009. Characterization of Sorbent Properties of Soil Organic Matter and Carbonaceous Geosorbents Using n-Alkanes and Cycloalkanes as Molecular Probes. Environ. Sci. Technol. 43, 393-400.

Finnish Meteorological Institute, http://ilmatieteenlaitos.fi.

Geisseler, D., Scow, K.M., 2014. Long-term effects of mineral fertilizers on soil microorganisms - A review. Soil Biology and Biochemistry 75, 54-63.

Jeng, A., Haraldsen, T.K., Vagstad, N., Grønlund, A., Tveitnes, S., 2004. Meat and bone meal as nitrogen fertilizer to cereals in Norway. Agricultural and Food Science 13, 268-275.

Karppinen, E.M., Stewart, K.J., Farrell, R.E., Siciliano, S.D., 2017. Petroleum hydrocarbon remediation in frozen soil using a meat and bonemeal biochar plus fertilizer. Chemosphere 173, 330-339.

Kauppi, S., Romantschuk, M., Strömmer, R., Sinkkonen, A., 2012. Natural attenuation is enhanced in previously contaminated and coniferous forest soils. Environ. Sci. Pollut. Res. 19, 53-63.

Kauppi, S., Sinkkonen, A., Romantschuk, M., 2011. Enhancing bioremediation of diesel-fuel-contaminated soil in a boreal climate: comparison of biostimulation and bioaugmentation. Int. Biodeterior. Biodegrad. 65, 359-368.

Kurola, J., Salkinoja - Salonen, M., Aarnio, T., Hultman, J., Romantschuk, M., 2005. Activity, diversity and population size of ammonia - oxidising bacteria in oil - contaminated landfarming soil. FEMS Microbiol. Lett. 250, 33-38.

Lazarovits, G., Conn, K.L., Potter, J., 1999. Reduction of potato scab, verticillium wilt, and nematodes by soymeal and meat and bone meal in two Ontario potato fields. Can. J. Plant Pathol. 21, 345-353.

Mikkonen, A., Yläranta, K., Tiirola, M., Dutra, L.A.L., Salmi, P., Romantschuk, M., Copley, S., Ikäheimo, J., Sinkkonen, A., 2018. Successful aerobic bioremediation of groundwater contaminated with higher chlorinated phenols by indigenous degrader bacteria. Water Res. 138, 118-128.

Mondini, C., Cayuela, M.L., Sinicco, T., Sánchez-Monedero, M.A., Bertolone, E., Bardi, L., 2008. Soil application of meat and bone meal. Short-term effects on mineralization dynamics and soil biochemical and microbiological properties. Soil Biol. Biochem. 40, 462-474.

Namkoong, W., Hwang, E.-Y., Park, J.-S., Choi, J.-Y., 2002. Bioremediation of diesel-contaminated soil with composting. Environ. Pollut. 119, 23-31.

Parajuli, A., Grönroos, M., Kauppi, S., Płociniczak, T., Roslund, M.I., Galitskaya, P., Laitinen, O.H., Hyöty, H., Jumpponen, A., Strömmer, R., 2017. The abundance of health-associated bacteria is altered in PAH polluted soils-Implications for health in urban areas? PloS one 12, e0187852.

Peltola, R., Salkinoja-Salonen, M., Pulkkinen, J., Koivunen, M., Turpeinen, A.-R., Aarnio, T., Romantschuk, M., 2006. Nitrification in polluted soil fertilized with fast-and slow-releasing nitrogen: A case study at a refinery landfarming site. Environmental pollution 143, 247-253.

Robertson, L.W., Hansen, L.G., 2015. PCBs: recent advances in environmental toxicology and health effects. University Press of Kentucky.

Roslund, M.I., Grönroos, M., Rantalainen, A.-L., Jumpponen, A., Romantschuk, M., Parajuli, A., Hyöty, H., Laitinen, O., Sinkkonen, A., 2018. Half-lives of PAHs and temporal microbiota changes in commonly used urban landscaping materials. PeerJ 6, e4508.

Simpanen, S., Dahl, M., Gerlach, M., Mikkonen, A., Malk, V., Mikola, J., Romantschuk, M., 2016. Biostimulation proved to be the most efficient method in the comparison of in situ soil remediation treatments after a simulated oil spill accident. Environ. Sci. Pollut. Res. 23, 25024-25038.

Simpanen, S., Yu, D., Mäkelä, R., Talvenmäki, H., Sinkkonen, A., Silvennoinen, H., Romantschuk, M., 2017. Soil vapor extraction of wet gasoline-contaminated soil made possible by electroosmotic dewatering-lab simulations applied at a field site. J Soils Sediments., 1-7. 
Sinkkonen, A., Kauppi, S., Simpanen, S., Rantalainen, A.-L., Strömmer, R., Romantschuk, M., 2013. Layer of organic pine forest soil on top of chlorophenol-contaminated mineral soil enhances contaminant degradation. Environ. Sci. Pollut. Res. 20, 1737-1745.

Valentine, R., Bradfield, J., 1954. The urea method for bacterial viability counts with the electron microscope and its relation to other viability counting methods. Microbiology 11, 349-357.

Varjani, S.J., 2017. Microbial degradation of petroleum hydrocarbons. Bioresour. Technol. 223, 277-286.

Wang, Y., Li, P., Jiang, Z., Sinkkonen, A., Wang, S., Tu, J., Wei, D., Dong, H., Wang, Y., 2016. Microbial community of high arsenic groundwater in agricultural irrigation area of Hetao Plain, Inner Mongolia. Front. Microbiol. 7, 1917.

Wongsa, P., Tanaka, M., Ueno, A., Hasanuzzaman, M., Yumoto, I., Okuyama, H., 2004. Isolation and characterization of novel strains of Pseudomonas aeruginosa and Serratia marcescens possessing high efficiency to degrade gasoline, kerosene, diesel oil, and lubricating oil. Curr. Microbiol. 49, 415-422.

Zhou, E., Crawford, R.L., 1995. Effects of oxygen, nitrogen, and temperature on gasoline biodegradation in soil. Biodegradation 6, 127-140. 


\section{High lights}

- Meat bone meal (MBM) was tested as a biostimulation agent in oil degradation

- Oil degradation was faster in MBM treatments compared to natural attenuation

- Soil pH stayed below 8 in MBM treated soil

- MBM is suitable for enhancing remediation of oil contaminated soils 